\title{
Outcome Based Assessment: A Case Study on Undergraduate Course on Control Systems
}

\author{
Ciji Pearl Kurian' ${ }^{1}$, V.I. George ${ }^{2}$, Anna Merine George ${ }^{3}$, Savitha G. Kini ${ }^{4}$, \\ 1,2,3,4 Professor Department of E\&E, M.I.T Manipal \\ 1ciji.pearl@manipal.edu
}

\begin{abstract}
The Outcome Based Assessment (OBA) has been one of the major concerns of most engineering departments in India since the National Board of Accreditation (NBA) has made it compulsory towards programme accreditation. Implementation of the OBA may not be an easy task when considering the mapping of the course outcome (CO) to Programme Outcomes (PO). This paper describe the analysis process of the $\mathrm{CO}$ and $\mathrm{PO}$ attainment for an undergraduate course on control systems, a subject, which is offered to 3 rd year students of Electrical \& Electronics Engineering at Manipal University. Two methods are incorporated for the assessment of course outcomes and PO attainment (1) direct measurement, and (2) indirect measurement. As a whole, this paper gives complete procedure and a sample analysis for Outcome Based Assessment starting from course curriculum development to its outcome attainment based on defined criteria's.
\end{abstract}

Keywords: Outcome Based Education, Course Outcome, Programme Outcome, Engineering Education

\section{Ciji Pearl Kurian}

Professor Department of E\&E, M.I.T Manipal

ciji.pearl@manipal.edu

\section{Introduction}

The implementation of Outcome Based Assessment (OBA) has been among the main focus of academic institutions in India, especially among engineering departments as India signed in as provisional member of the Washington Accord through the National Board of Accreditation Council (NBA) [1-2]. NBA has made OBA implementation as a compulsory practice in order for the programme to attain accreditation. The implementation of OBA is intended to ensure the curricula design fulfils the programme outcome and programme education objective, which shall reflect the achievement to the university's mission and vision. The concept of OBE is about developing the curricular structure based on what the learner are expected to achieve at the end of the education programme [3]. In order for OBE to be successfully implemented, there is a need to have the basic components which are: (i) University Mission \& Vision (ii) Programme Educational Objectives (PEO); (iii) Programme Outcomes (PO) and (iv) Course Outcomes (CO) [4-5].

OBA implementation involves a regular and systematic data collection process in the departments. In addition, the execution of OBA is complex as the mapping of Course Outcome (CO) to PO may not necessarily be mapped to one item only. It reflects student centered learning focuses on measuring student performance since joining to throughout their career, with emphasis on 3-5 years of graduation. 
Electrical \& Electronics engineering programme features core courses that cover fundamental electrical engineering science and design areas to help students gain in depth knowledge of engineering principles. Students also have the opportunity to select a variety of technical elective courses and open elective courses from other disciplines. Mini projects, seminar, major project, industrial training and technical club activities will help them to practice professional approach to learning. Students are encouraged to join, participate, and help organize conferences, student paper contest and industry institute interactions. IE (E\&E) student chapter, IEEE student branch and robotics club is active with E\&E student participation.

Curriculum development process is shown in Fig. 1; it is framed and approved by Board of studies and Senate. The structure of the curriculum must provide both breadth and depth across the range of engineering topics implied by the title of the program. E\&E curriculum is mainly designed based on lead societies IEEE. The generation of power, efficient use of electrical energy and control of electrical machines require an in depth study modeling and control of such systems. So the following courses are introduced.

L Linear Control Theory (Professional Core)

․ Modern Control Theory (Professional Core)

4 Advanced Control Systems (Program Elective)

Course coordinator of the course will provide a detailed plan for the semester including lecture plan, tutorials and evaluation plan. This will help to maintain uniformity of teaching learning process across the sections.

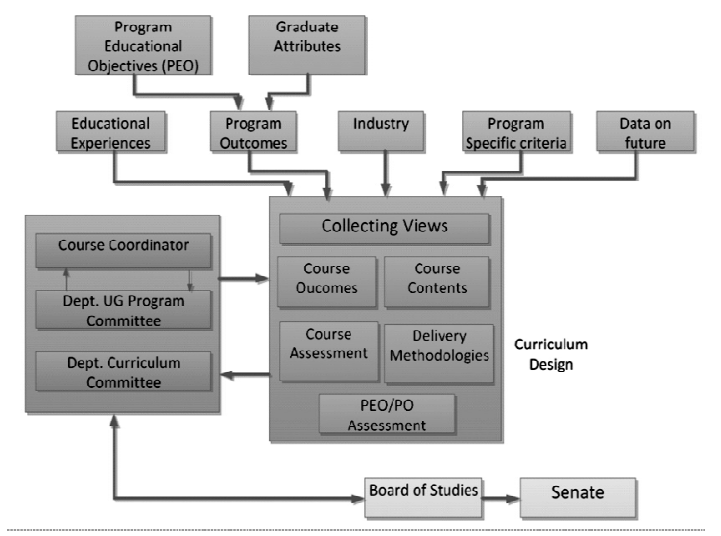

Fig.1: Curriculum development process

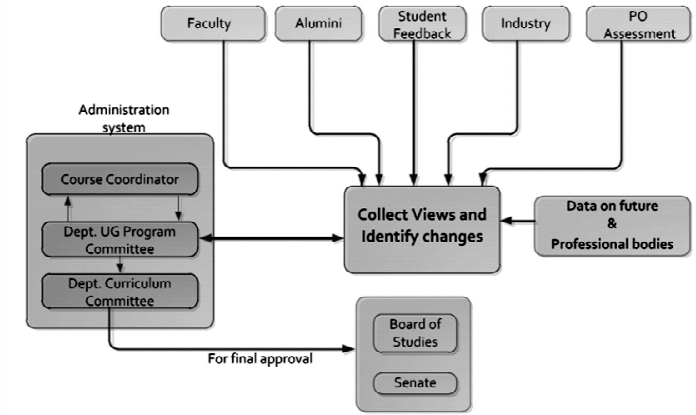

Fig.2: Process involved in improving the curriculum

Fig. 2 shows the process involved in improving the curriculum which takes the feedback of industry and alumni also. Feedback from industries helps in future development of course structure to cater to their needs and also to introduce new and upcoming technologies. Interaction with alumni and current students helps the future graduates to decide on their long term goals

\section{Programme Educational Objective (PEO)}

The plan for outcome based education starts with defining vision and mission of the department in line with the institute vision and mission by taking input from various stake holders such as faculty, top management, professional bodies, alumni, industries and graduating students. The defined mission and vision is approved by the Department Curriculum Committee (DCC) ensuring consistency with the vision and mission of the Institute. Programme Educational Objectives (PEO) is based on NBA Graduate attributes and the present context of Engineering [4-6]. Each program is designed to prepare students for continued learning and successful careers in industry, academia and research. The curriculum is one of the main tools to prepare students in achieving PEOs. Therefore, the relevance of the courses in the program specific curriculum to PEO needs to be quantified in order to establish their level of support to PEO. Various administrative systems help in ensuring the Achievement of the PEOs of the department. Program Educational Objectives (PEOs) relate to the career and professional accomplishments of students after they graduate from the program. Consequently, assessment and evaluation of the objectives requires assessment tools that can be applied after graduation. However, keeping the significance of contribution of the curriculum and the assessment opportunities such as placement data and higher education entrance performance, these assessments are taken as supplementary evidence. Consistency of the PEOs with the mission of the department is an important concern. 


\section{Course on Control Systems}

This section presents the description of the course on Control System considered for the discussion. Linear Control Theory is a first level course that emphasize on classical control theory. It is based on firm mathematical foundations and has rigorous design tools which improves the problem solving and design skills. The course deals with fundamental concepts, control system terminology, principles of system modeling, analysis and control design. The course focuses on linear time invariant continuous time systems. The course explains the concept of stability and various graphical methods for stability analysis and describes the design performance criteria in detail. Proportional, PI, PD and PID controller design and analysis are discussed comprehensively. Students are also familiarized to use MATLAB for controller design and analysis. Finally an introduction to state space modeling is contained in the course, the more analysis and design using state space modeling approach is discussed in the next level course. At the end of the course the students will be able to model electrical, mechanical and electro- mechanical systems, design controllers for various interdisciplinary applications and use MATLAB as a tool for verifying theoretical concepts.

\section{Programme outcomes}

PO1: Apply the knowledge of mathematics, science and engineering to solve the electrical \& electronics engineering problems.

PO2:Identify, formulate and solve power \& energy system problems.

PO3: Design and conduct experiments on analog and digital electronic systems to analyze and interpret data.

PO4: Apply the principles of electrical circuits and machines for testing and analysis.

PO5: Design power electronic systems and control systems as per needs and specifications

PO6: Model and simulate signals and systems, control systems and energy systems using modern engineering tools.

PO7: Practice professional ethics and engage in lifelong learning.

PO8: Communicate effectively and work in a team using common tools to achieve project objectives.

PO9: Recognize professional and personal responsibility towards the community.
Table 1: Mapping of Course Outcome with PO

\begin{tabular}{|c|c|c|}
\hline C01 & $\begin{array}{l}\text { Derive the Transfer function \& State } \\
\text { space modeling of linear time invariant } \\
\text { systems. }\end{array}$ & $\begin{array}{l}\text { P01,P04, } \\
\text { PO6 }\end{array}$ \\
\hline C02 & $\begin{array}{l}\text { Use signal -flow graphs and block } \\
\text { diagrams to derive systems input -output } \\
\text { relations. }\end{array}$ & $\begin{array}{l}\text { P01,P04, } \\
\text { P06 }\end{array}$ \\
\hline C03 & $\begin{array}{l}\text { Describe quantitatively the transient } \\
\text { response and frequency response of } \\
\text { linear time invariant systems. }\end{array}$ & $\begin{array}{l}\text { P01,P04, } \\
\text { P06 }\end{array}$ \\
\hline C04 & $\begin{array}{l}\text { Determine absolute and relative stability } \\
\text { of linear systems. }\end{array}$ & $\begin{array}{l}\text { P01,P05, } \\
\text { P06 }\end{array}$ \\
\hline C05 & $\begin{array}{l}\text { Design controllers to meet steady state } \\
\text { error performance and transient response } \\
\text { specifications. }\end{array}$ & $\begin{array}{l}\text { P01,P04, } \\
\text { P06 }\end{array}$ \\
\hline
\end{tabular}

Table 1 shows mapping of control system course with PO where the strength of the correlation is indicated as - strong, moderate,low.

\section{Attainment of the POs}

Different course delivery methods/modes such as power point presentations, tutorial, lecture combined with simulation and discussion etc. are used to deliver the course and measure the effectiveness of these methods for the attainment of the POs. This may be further justified using the indirect assessment methods such as course-end surveys. Mapping of course outcome with question paper helps to assess the knowledge level, design and analysis content. Table 2 gives the mapping of course outcome with internal examinations, assignment and end semester examinations. Table 3 shows the delivery modes used for linear control theory course.

Table 2: Course Outcome - Direct Assessment Mapping

\begin{tabular}{|l|l|l|l|l|l|l|l|l|}
\hline C0 & T1 & T2 & A1 & A2 & A3 & A4 & A5 & $\begin{array}{l}\text { End Sem. } \\
\text { (Regular) }\end{array}$ \\
\hline C01 & X & & X & & & & & X \\
\hline C02 & X & & X & X & & & & X \\
\hline C03 & & X & & X & X & & & X \\
\hline C04 & & X & & & X & X & & X \\
\hline C05 & & & & & & X & X & X \\
\hline
\end{tabular}


Table 3: Course -Content Delivery Mapping

\begin{tabular}{|c|c|c|c|c|c|c|c|}
\hline $\begin{array}{c}\text { Board } \\
\text { and } \\
\text { Chalk }\end{array}$ & $\begin{array}{c}\text { Power } \\
\text { Point } \\
\text { Presentation }\end{array}$ & $\begin{array}{c}\text { QIEEE/ } \\
\text { Video } \\
\text { Lectures }\end{array}$ & $\begin{array}{c}\text { Seminars / } \\
\text { Mini } \\
\text { Project } \\
\text { /team } \\
\text { based } \\
\text { assignments }\end{array}$ & $\begin{array}{c}\text { Tutorial } \\
\text { / } \\
\text { Problem } \\
\text { Sheet }\end{array}$ & $\begin{array}{c}\text { Debate/ } \\
\text { Group } \\
\text { Discussion } \\
\text { Quiz/ }\end{array}$ & $\begin{array}{c}\text { simulation/ } \\
\text { Demonstration }\end{array}$ & $\begin{array}{c}\text { PO's } \\
\text { attained }\end{array}$ \\
\hline $\mathbf{X}$ & $\mathbf{X}$ & & & $\mathbf{X}$ & $\mathbf{X}$ & $\mathbf{X}$ & $\begin{array}{c}\text { PO1, } \\
\text { PO4, } \\
\text { PO5, } \\
\text { PO6, }\end{array}$ \\
\hline
\end{tabular}

Table 4: Direct and Indirect Assessment Methodology

\begin{tabular}{|l|ll|}
\hline $\begin{array}{l}\text { Direct } \\
\text { Assessment }\end{array}$ & $\begin{array}{l}\text { PO assessment through Course results. } \\
\text { Mapping of course outcome with } \\
\text { question paper. }\end{array}$ \\
\hline $\begin{array}{l}\text { Indirect } \\
\text { Assessment }\end{array}$ & $\begin{array}{l}\text { Course feedback at the end of each } \\
\text { course }\end{array}$ \\
& - $\begin{array}{l}\text { Graduate survey at the end of the } \\
\text { program }\end{array}$ \\
\hline
\end{tabular}

The program outcomes are assessed with the help of course outcomes of the relevant courses by result analysis. Direct measures are provided through direct examinations i.e. through end semester examination grades of the respective courses. End semester grade reflects continuous evaluation including 2 internal tests, assignments and the end semester examination results. Indirect assessment strategies are implemented by embedding them in the course feedback and Graduate survey. Finally, program outcomes are assessed with above mentioned data with respect to the specified target.

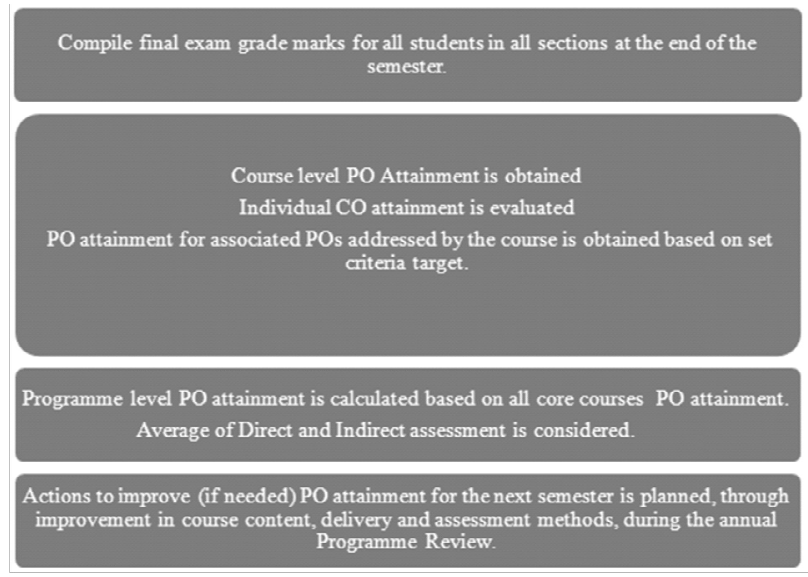

Fig.3 Process flow chart for PO attainment analysis

\section{Performance Criteria Target}

For direct assessment, $65 \%$ of students achieve a minimum of grade $\mathrm{C}$ in the respective courses. If the percentage of $\mathrm{PO}$ attainment is $75 \%$ or more taking the average of direct and indirect assessment, the PO is considered as achieved.
Sample Analysis is shown in Fig. 4 \& Fig. 5 to indicate results of Evaluation of PO5 and PO6.

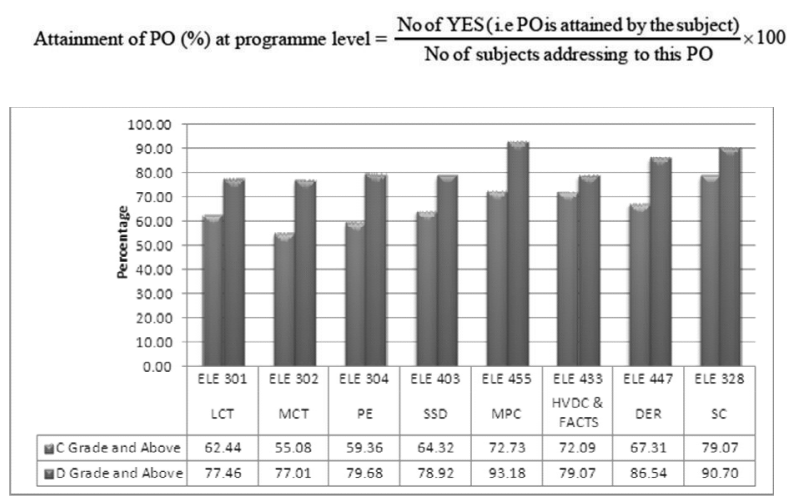

Fig.4 Sample Evaluation of PO5

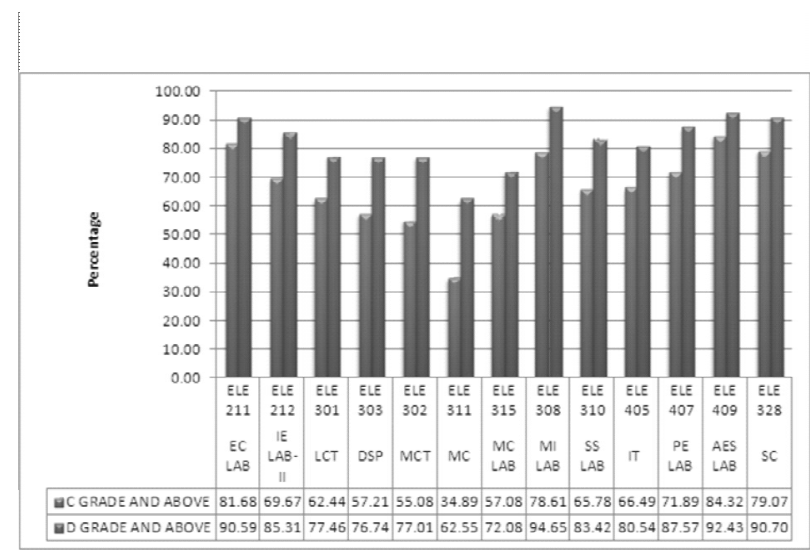

Fig.5 Sample Evaluation of PO6

\section{Indirect Assessment (Graduates Survey)}

Table 5: Analysis of Graduate / Exit survey of 2014 passed out students.

\section{Criteria: Above Good is considered as 'YES'. \\ $75 \%$ of samples YES PO is attained.}

\begin{tabular}{|l|l|c|}
\hline 1 & Solve engineering problems. & P01, P02 \\
\hline 2 & $\begin{array}{l}\text { Design a component or process as } \\
\text { per needs and specifications. }\end{array}$ & P03, P05 \\
\hline 3 & $\begin{array}{l}\text { Use modern tools to analyze } \\
\text { engineering problems. }\end{array}$ & P06, P04 \\
\hline 4 & $\begin{array}{l}\text { Work in a team, carry out multi } \\
\text { disciplinary projects. }\end{array}$ & P07, P08, P09 \\
\hline 5 & $\begin{array}{l}\text { Participate and succeed in } \\
\text { competitive exams and higher } \\
\text { studies. }\end{array}$ & P07 \\
\hline
\end{tabular}


According to the analysis carried out using 88 samples all the POs are attained.

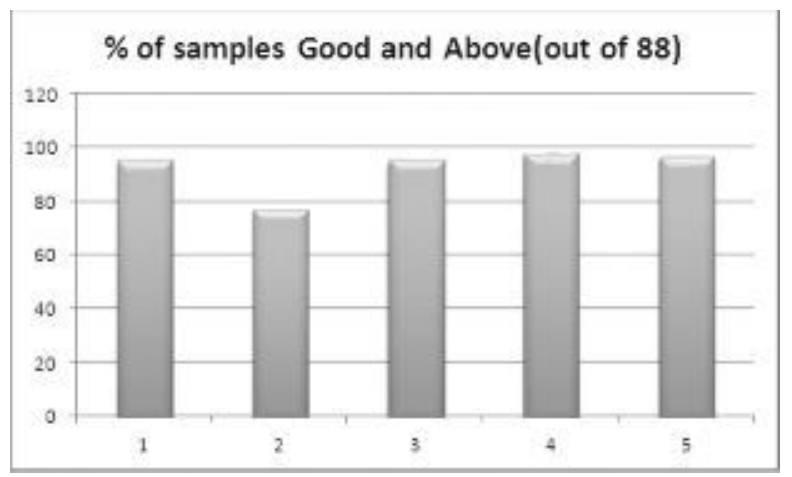

Fig.6: Results of Indirect Assessment

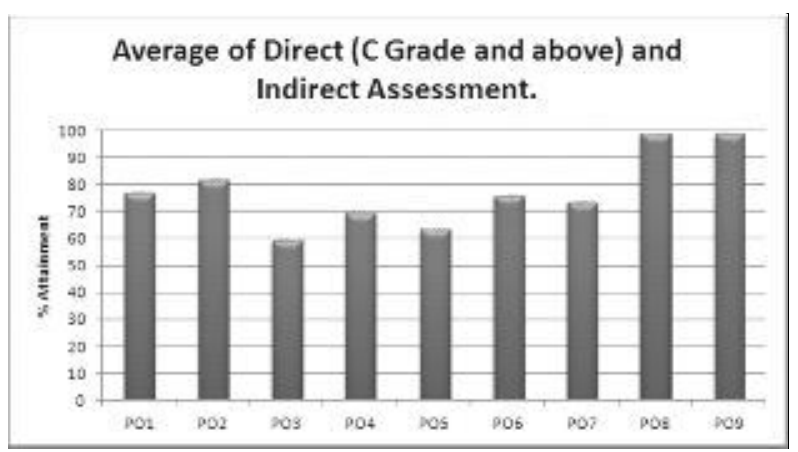

Fig. 7: Average of Direct and Indirect Assessment

\section{Course Outcome Assessment:}

Table 6: Course End Survey (Indirect Assessment) Analysis

\begin{tabular}{|c|c|c|c|c|}
\hline Excellent(E) & Good(G) & Average(A) & Poor(P) & $\begin{array}{c}\text { No } \\
\text { Comment(NC) }\end{array}$ \\
\hline 5 & 4 & 3 & 2 & 1 \\
\hline
\end{tabular}

\begin{tabular}{|c|c|c|c|c|c|c|c|c|c|c|}
\hline & Question & & Surv & y data & & & sessn & & & \\
\hline & Questors & $\mathrm{CO}$ & $\begin{array}{l}\text { No. } \\
\text { of } \\
\text { res } \\
\text { pon } \\
\text { ses }\end{array}$ & $\begin{array}{l}\text { Satisf } \\
\text { actio } \\
\text { n no. } \\
\text { natisf } \\
\text { satisf } \\
\text { ied }\end{array}$ & $\begin{array}{l}5 \\
\mathrm{E}\end{array}$ & $\begin{array}{l}4 \\
\mathrm{G}\end{array}$ & $\begin{array}{l}3 \\
\mathrm{~A}\end{array}$ & $\frac{1}{2}$ & $\begin{array}{l}1 \\
\mathrm{NC}\end{array}$ & $\begin{array}{l}\text { Asse } \\
\text { ssme } \\
\text { nt } \\
\text { Point } \\
>-3 \text {, } \\
\text { satisf } \\
\text { ied }\end{array}$ \\
\hline $\begin{array}{l}\mathbf{Q} \\
\mathbf{1}\end{array}$ & \begin{tabular}{|l} 
How good \\
are you in \\
deriving \\
Transfer \\
function \\
models \& \\
State space \\
models of \\
linear time \\
invariant \\
systems.
\end{tabular} & $\mathrm{CO} 1$ & 175 & 167 & 36 & 77 & 54 & 7 & 1 & 3.80 \\
\hline$\frac{\mathbf{Q}}{2}$ & \begin{tabular}{|l} 
How \\
comfortable \\
are you in \\
using signal- \\
flow graphs \\
and block \\
diagrams to \\
derive \\
systems \\
input-output \\
relations.
\end{tabular} & $\mathrm{CO} 2$ & 174 & 170 & 43 & 86 & 41 & 4 & 0 & 3.97 \\
\hline
\end{tabular}

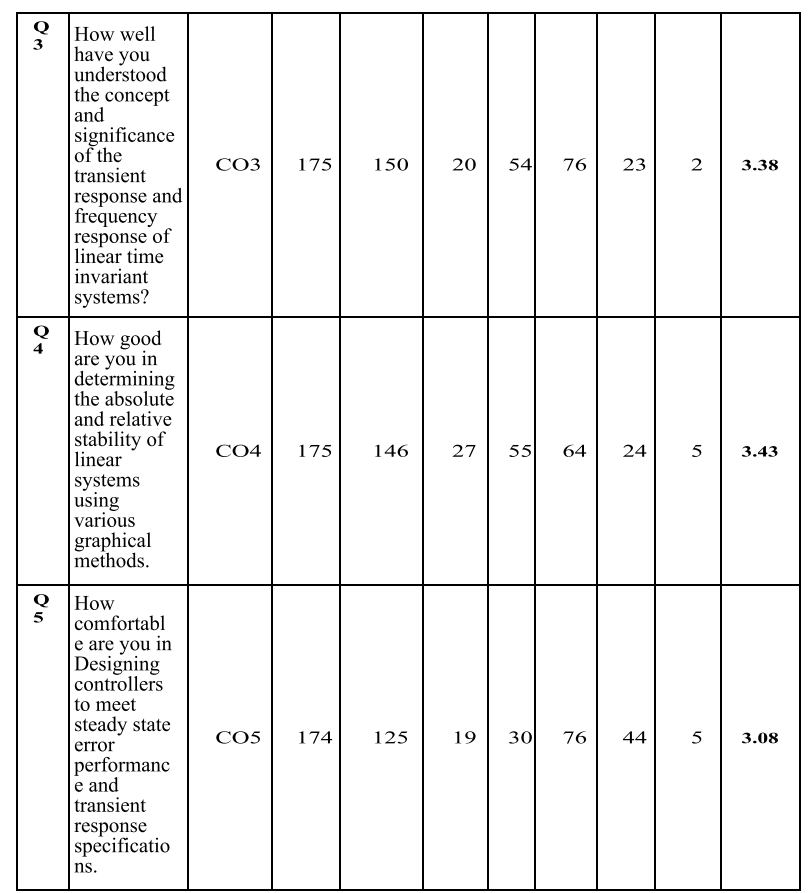

Table 7: Result (Direct Assessment) Analysis (November 2014 Exam)

Result Analysis (End Semester Examination November 2014)

\begin{tabular}{|c|c|c|c|c|c|c|}
\hline & $\begin{array}{l}\text { Qn } \\
.1\end{array}$ & $\begin{array}{l}\text { Qn } \\
.2\end{array}$ & $\begin{array}{l}\text { Qn } \\
.3\end{array}$ & $\begin{array}{l}\text { Qn } \\
.4\end{array}$ & $\begin{array}{l}\text { Qn } \\
.5\end{array}$ & $\begin{array}{l}\text { Qn } \\
.6\end{array}$ \\
\hline $\begin{array}{l}\text { Question-CO } \\
\text { Mapping }\end{array}$ & $\begin{array}{l}\text { CO } \\
1, \\
\text { co } \\
2\end{array}$ & $\begin{array}{l}\text { CO } \\
2, \\
\text { CO } \\
3\end{array}$ & $\begin{array}{l}\text { CO } \\
3 \text {, } \\
\text { CO } \\
4\end{array}$ & $\begin{array}{l}\text { CO } \\
4, \\
\text { CO } \\
5\end{array}$ & $\begin{array}{c}\text { CO } \\
3, \\
\text { CO } \\
4\end{array}$ & $\begin{array}{l}\text { Co } \\
1, \\
\text { CO } \\
5\end{array}$ \\
\hline Average & $\begin{array}{c}5.5 \\
6\end{array}$ & $\begin{array}{c}3.7 \\
4\end{array}$ & $\begin{array}{c}4.9 \\
8\end{array}$ & $\begin{array}{c}3.7 \\
4\end{array}$ & $\begin{array}{c}6.1 \\
7\end{array}$ & $\begin{array}{c}4.4 \\
6\end{array}$ \\
\hline Minimum & o & o & O & O & o & o \\
\hline Maximum & 10 & 6.5 & 10 & 10 & 10 & 10 \\
\hline $\begin{array}{l}\text { No. of students with } \\
\text { Excellent } \\
\text { Performance }(>8) \text { E }\end{array}$ & 30 & o & 24 & 17 & 67 & 19 \\
\hline $\begin{array}{l}\text { No. of students with } \\
\text { Good Performance } \\
(>6 \&<8) \text { G }\end{array}$ & 73 & 10 & 38 & 17 & 33 & 15 \\
\hline $\begin{array}{l}\text { No. of students with } \\
\text { Average Performance } \\
(>4 \&<6) \text { A }\end{array}$ & 44 & 85 & 60 & 35 & 29 & 26 \\
\hline $\begin{array}{l}\text { No. of students with } \\
\text { Below average } \\
\text { Performance }(>2 \\
\&<4) \text { B }\end{array}$ & 18 & 52 & 38 & 45 & 24 & 41 \\
\hline $\begin{array}{l}\text { No. of students with } \\
\text { Poor Performance } \\
(>0 \&<2) \text { P }\end{array}$ & 11 & 20 & 13 & 40 & 18 & 11 \\
\hline $\begin{array}{c}\text { Course outcome } \\
\text { Assessment Point }= \\
\begin{array}{c}(5 \times E+4 \times G+3 \times A+2 \times B+1 \\
\times P) / N \\
>=3 \text { Satisfied }\end{array}\end{array}$ & 3.51 & 2.51 & 3.13 & 2.52 & 3.63 & 2.91 \\
\hline $\begin{array}{l}\text { No. of students } \\
\text { attempted the } \\
\text { question, } N\end{array}$ & 177 & 167 & 173 & 154 & 171 & 112 \\
\hline $\begin{array}{l}\text { \% Students } \\
\text { attempted }\end{array}$ & $\begin{array}{l}99 \\
\%\end{array}$ & $\begin{array}{l}93 \\
\%\end{array}$ & $\begin{array}{l}97 \\
\%\end{array}$ & $\begin{array}{l}86 \\
\%\end{array}$ & $\begin{array}{l}96 \\
\%\end{array}$ & $\begin{array}{l}63 \\
\%\end{array}$ \\
\hline $\begin{array}{l}\text { No. of students with } \\
\text { marks more than or } \\
\text { equal to avg. }\end{array}$ & 103 & 95 & 93 & 69 & 94 & 44 \\
\hline $\begin{array}{l}\text { \% students with } \\
\text { marks more than or } \\
\text { equal to avg. }\end{array}$ & $\begin{array}{l}58 \\
\%\end{array}$ & $\begin{array}{l}53 \\
\%\end{array}$ & $\begin{array}{l}52 \\
\%\end{array}$ & $\begin{array}{l}39 \\
\%\end{array}$ & $\begin{array}{l}53 \\
\%\end{array}$ & $\begin{array}{l}25 \\
\%\end{array}$ \\
\hline
\end{tabular}


Table $5 \& 6$ shows the level of $\mathrm{CO}$ attainment. Wherever the course outcome is not attained the faculty coordinator along with fellow teachers should decide upon the action plans to improve the system. In this particular study course end survey as well as course outcome question paper mapping is showing satisfactory attainment of CO's. In order to obtain continuous improvement, set target must be increased and analyze the assessment. The feedback from alumni and industry experts arise the need for the curriculum design with more industry institute interaction and simulation assisted study.

\section{Acknowledgement}

We would like to acknowledge the NBA team members of the Department of E\&E, M.I.T Manipal University for the data collection of this case study. Major part of this is prepared for the SAR report of B.Tech E\&E programme of Manipal University.

\section{Conclusion}

OBE promotes a continuous quality improvement on the programme based on regular evaluation of the attainment of COs \& POs. POs are assessed in general with the result end surveys and COs are assessed through a rigorous process of question to $\mathrm{CO}$ attainment. This requires an active role of subject coordinator in deciding sensible question paper pattern to achieve the outcome. Subject coordinator holds a big responsibility of designing the subject curricula to setting up of question paper that can ease the attainment analysis process. All assessments to be implemented in the course (e.g., Assignment, Test, Project, and Final Exam) should be prepared before the beginning of the semester. This is achievable if the subject coordinator has sufficient experience to plan for. Continuous improvement may be implemented by focusing on the issues at hand. However, managing extensive data is time consuming and deters the commitment of academic members towards effective OBE implementation. An Academic Management System should develop a system that provides standardized CO-PO attainment analysis. Finally, the effectiveness of OBE implementation goes back to the practice of the concerned subject coordinator and institutional facility available

\section{References}

[1]Masni-Azian, A., Rahimah, A.H. and M.S., Othman, IOSR Journal of Research \& Method in Education (IOSR-JRME) e-ISSN: 2320-7388, pISSN: 2320-737X. Volume 4, Issue 2 Ver. III (MarApr. 2014), PP 55-61, www.iosrjournals.org.

[2]Ungku Anisa Ungku Amirulddin, Miszaina Osman, Fazrena Azlee Hamid, "Analysis of Programme Outcomes Achievement for Electrical Engineering Programmes in UNITEN", International Conference on Engineering Education (1CEED 2009), December 7-8, 2009, Kuala Lumpur, Malaysia.

[3] Mahadevan, Ramachandran; Shivaprakash, N C ; Khobragade, N T; Raju, KVL ; Nageswara Rao, V $\mathrm{V}$, "Implementing a sustainable methodology for assessment of course outcomes and program outcomes in an Indian Engineering Institute", IEEE International Conference on Teaching, Assessment and Learning for Engineering (TALE), 2013.

[4] National Board of Accreditation (NBA), India, www.nbaind.org.

[5] Manual of Accreditation, National Board of Accreditation(NBA), All India Council for Technical Education, New Delhi, India, 20042013.

[6]Accreditation Board for Engineering \& Technology (ABET),www.abet.org. 